\title{
Diversity and biomass of native macrophytes are negatively related to dominance of an invasive Poaceae in Brazilian sub-tropical streams
}

\author{
A diversidade e a biomassa de macrófitas nativas são negativamente relacionadas
} com a dominância de uma Poaceae invasora em riachos sub-tropicais

Luiz Felipe Gonçalves Fernandes ${ }^{1}$, Mariana Carolina Teixeira ${ }^{2}$ and Sidinei Magela Thomaz ${ }^{3}$

${ }^{1}$ Departamento de Biologia, Universidade Estadual de Maringá,

Av. Colombo, 5790, Bl. G90, CEP 82020-900, Maringá, PR, Brazil

e-mail: luizfelipegf@gmail.com

${ }^{2}$ Pós-graduação em Ecologia de Ambientes Aquáticos Continentais,

Universidade Estadual de Maringá, Av. Colombo, 5790, Bl. G90, CEP 82020-900, Maringá, PR, Brazil

e-mail: m_c_teixeira@yahoo.com

${ }^{3}$ Núcleo de Pesquisas em Limnologia, Ictiologia e Aquicultura - Nupélia,

Universidade Estadual de Maringá, Av. Colombo, 5790, Bl. G90, CEP 82020-900, Maringá, PR, Brazil

e-mail: smthomaz@nupelia.uem.br

\begin{abstract}
Besides exacerbated exploitation, pollution, flow alteration and habitats degradation, freshwater biodiversity is also threatened by biological invasions. This paper addresses how native aquatic macrophyte communities are affected by the non-native species Urochloa arrecta, a current successful invader in Brazilian freshwater systems. We compared the native macrophytes colonizing patches dominated and non-dominated by this invader species. We surveyed eight streams in Northwest Paraná State (Brazil). In each stream, we recorded native macrophytes' richness and biomass in sites where $U$. arrecta was dominant and in sites where it was not dominant or absent. No native species were found in seven, out of the eight investigated sites where $U$. arrecta was dominant. Thus, we found higher native species richness, Shannon index and native biomass values in sites without dominance of $U$. arrecta than in sites dominated by this invader. Although difficult to conclude about causes of such differences, we infer that the elevated biomass production by this grass might be the primary reason for alterations in invaded environments and for the consequent impacts on macrophytes' native communities. However, biotic resistance offered by native richer sites could be an alternative explanation for our results. To mitigate potential impacts and to prevent future environmental perturbations, we propose mechanical removal of the invasive species and maintenance or restoration of riparian vegetation, for freshwater ecosystems have vital importance for the maintenance of ecological services and biodiversity and should be preserved.
\end{abstract}

Keywords: signal grass, nvasive macrophytes, freshwater, biodiversity.

Resumo: Juntamente com a exploração exacerbada, poluição, alteração de regime hidrológico e degradação de habitas as invasões biológicas são consideradas uma ameaça à biodiversidade dos ecossistemas aquáticos continentais. Nesse sentido, a Poaceae Urochloa arrecta é reconhecida como uma invasora bem sucedida em ambientes aquáticos brasileiros. Nós comparamos bancos de macrófitas dominados e não-dominados por esta invasora. Foram amostrados oito córregos no noroeste do Estado do Paraná (Brasil). Em cada córrego registramos a riqueza e a biomassa de macrófitas nativas em locais onde $U$. arrecta era dominante e em locais onde ela não dominava ou era ausente. Em sete dos oito locais onde $U$. arrecta dominava, náo haviam macrófitas nativas. Assim, encontramos maiores riqueza de espécies nativas, índice de Shannon e biomassa nativa nos locais não dominados por $U$. arrecta com relação aos locais dominados. Apesar da dificuldade em se extrair conclusóes sobre as causas dessas diferenças, inferimos que a elevada biomassa da invasora pode ser a principal fonte de alteraçóes nesses ambientes, com consequentes impactos na comunidade nativa. Porém, resistência biótica oferecida por locais com maior riqueza de espécies nativas seria uma explicação alternativa para nossos resultados. Para mitigar os potenciais impactos e prevenir futuras perturbaçóes ecológicas, propomos a remoção mecânica dessa espécie invasora e a preservação e/ou restauração da vegetação ripária, pois ambientes de água doce são de importância vital para a manutençấo de serviços ambientais e biodiversidade.

Palavras-chave: capim-braquiária, macrófitas invasoras, córregos, biodiversidade. 


\section{Introduction}

Biological invasions are one of the most important environmental disruptions to aquatic ecosystems (Strayer, 2010). Invasive species are those which become extremely successful in their own (native) or new (exotic) habitats and put new pressures on the environment and resident species. In freshwater ecosystems, which are especially vulnerable to the anthropogenic impacts (Dudgeon et al., 2006), invasions are recurrent and their effects are several (Strayer, 2010).

Aquatic macrophytes have many important roles in the maintenance of biodiversity and functioning of freshwater ecosystems (e.g. Engelhardt and Ritchie, 2001). Macrophyte stands house a great diversity of organisms that rely on them for food (Casatti et al., 2003; Pelicice and Agostinho, 2006) or shelter and refuge (Agostinho et al., 2007). They also participate in biogeochemical (Urban et al., 2009) and hydrodynamic (Kleeberg et al., 2010) processes and determine many abiotic features of water, such as dissolved oxygen concentrations (Caraco et al., 2006), underwater light (Rodríguez et al., 2012) and turbidity (Horppila and Nurminen, 2003).

However, they also have traits such as vegetative reproduction and rapid growth that make them potential invaders (Santamaría, 2002). Among invasive macrophytes is the Poaceae Urochloa arrecta (Hack. ex T. Durand \& Schinz) Morrone \& Zuloaga, popularly known as African signal grass or tanner grass (USDA, 2013). This is a highly invasive grass native to Africa (USDA, 2013) and is currently found in several natural and artificial aquatic ecosystems in South America (Reinert et al., 2007; Pott et al., 2011). Due to its resemblance to another invasive grass, it has been also identified as Urochloa subquadripara (Trin.) R.D. Webster [syn. Brachiaria subquadripara (Trin.) Hitchc., Brachiaria arrecta (Hack.) Stent.] in some former studies in Brazilian reservoirs and lakes (e.g. Michelan et al., 2010; Thomaz and Michelan, 2011), but according to a recent phylogenetic study and descriptions in Salariato et al. (2010), it is now known to be Urochloa arrecta.

Changes in the communities of aquatic macrophytes lead to changes in abiotic conditions and consequently in the communities of associated organisms, which can, through trophic interactions, extend the effects to the whole ecosystem (Shultz and Dibble, 2012). Such alterations can persist in the invaded areas even long after the invaders have been removed (Corbin and D'Antonio, 2012).
Previous studies have suggested significant negative effects of aquatic invasive Poaceae on diversity of aquatic macrophytes in reservoirs and lakes (Michelan et al., 2010), and also in rivers (Amorim, 2012). Species of aquatic Poaceae (including $U$. arrecta) have also been noticed in such ecosystems in the states of Paraná and São Paulo (personal observations, Martins et al., 2008; Domingos et al., 2011). According to Bunn et al. (1998), streams invaded by a grass (Brachiaria mutica Forssk. Stapf) similar to $U$. arrecta have their morphology and hydrology altered, with higher siltation rates and further impacts. These findings are a matter of concern because streams supply larger water bodies and usually hold high biological diversity (Penczak et al., 1994, Melo and Froelich, 2001).

Considering the great potential of aquatic grasses to become invasive and affect aquatic ecosystems, we investigated streams colonized by the exotic $U$. arrecta and hypothesized that its establishment is negatively associated with the success of native aquatic macrophytes. We predict that stands dominated by the invader have lower taxa richness, lower taxa Shannon diversity, and lower native plant biomass in comparison with those stands where the invasive is non-dominant or absent.

\section{Methods}

We visited 20 streams in the northwest region of Paraná State, aiming to find streams with patches dominated and patches not dominated by $U$. arrecta . We found eight streams which shared both types of patches close to each other (Figure 1). In total 16 patches, which varied in size from approximately 2 to $20 \mathrm{~m}^{2}$, were surveyed, eight dominated and eight not dominated. We recorded the species and their relative abundance within a $1 \times 1 \mathrm{~m}$ square, divided into 25 equal smaller squares $(0.2 \times 0.2 \mathrm{~m})$. The square was placed over the stands, in the most central position possible, and we checked how many small squares each taxa occupied. Macrophytes were identified according to specialized literature to the smallest taxonomic level as possible (Pott and Pott, 2000; Salariato et al., 2010).

To measure plants' biomass, we placed another $0.25 \times 0.25 \mathrm{~m}$ square in the center of the large square and collected all plants located inside it. Only material that was above water surface was collected. The collected plants were separated by taxa, dried until constant weight and weighed. Some taxa could not be identified to species, for their reproductive structures were absent. However, this apparent 


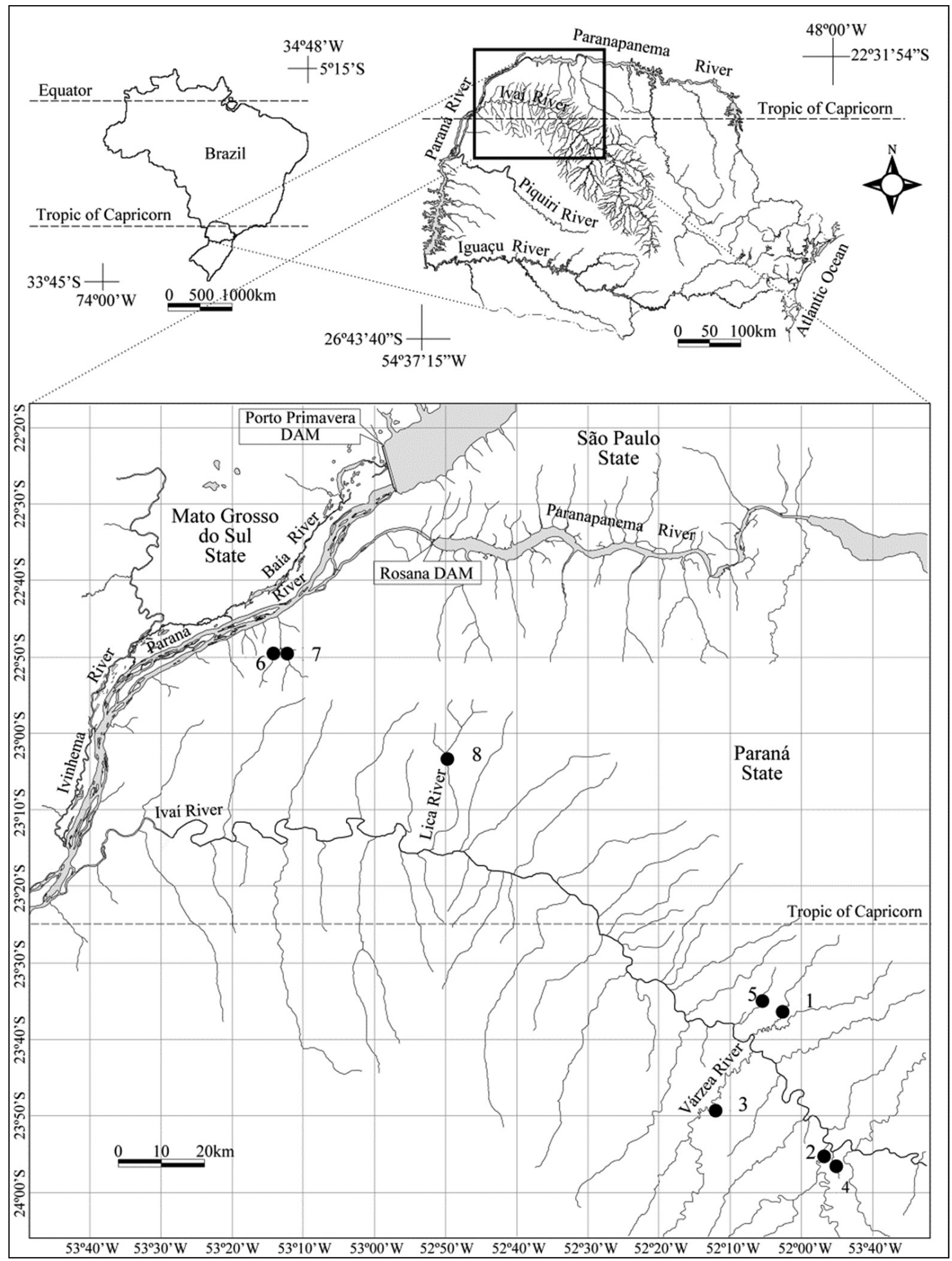

Figure 1. Paraná State map and sampling locations (1 to 8 ).

limitation did not compromise the aim of this study, which was not to make a taxonomic survey of macrophytes, but to compare the attributes of macrophyte assemblages (in terms of taxa richness and diversity) of sites dominated with sites nondominated by the invasive Poaceae.
We constructed taxa cumulative curves considering squares as sampling units to locals dominated or not by $U$. arrecta to assess sampling sufficiency and to compare richness in invaded with non or less-invaded sites. The curves were made with the software Estimates 8.2.0 (Colwell, 2005). We 
calculated Shannon diversity values from the relative abundance of each taxa, expressed by the number of smaller squares the species occupied divided by the total number of occupied small squares. To identify differences in the communities, we used paired t-tests with dominance or non-dominance of $U$. arrecta as the grouping factor for taxa richness and biomass, in separate tests. Statistical analyses were carried with STATISTICA 8 (StatSoft, 2007).

\section{Results}

We recorded a total of 20 taxa of aquatic macrophytes in the eight streams, not including $U$. arrecta (Table 1). Among the taxa, the most frequent were Poaceae sp.1 (5 occurrences), Commelina diffusa and Myriophyllum aquaticum (3 occurrences each), Heteranthera sp., Cyperus sp. and Hymenachne sp. (2 occurrences each), while other taxa occurred only once each.

The cumulative curves did not reach an asymptote for the non-dominated sites, indicating more species could be found if our sampling efforts were increased. For the dominated sites the number of taxa was almost constant since in most of them we found mono-specific stands of $U$. arrecta, and only one quadrat had other two species in addition to this Poaceae (Figure 2).

Shannon diversity index varied from 0.76 to 1.33 in sites not dominated by $U$. arrecta. This index

Table 1. Taxa recorded in patches dominated and nondominated by Urochloa arrecta in the surveyed streams.

\begin{tabular}{ll}
\hline $\begin{array}{c}\text { U. arrecta } \\
\text { dominated patches }\end{array}$ & \multicolumn{1}{c}{$\begin{array}{c}\text { Non-dominated } \\
\text { patches }\end{array}$} \\
\hline Poaceae sp.1 & Azolla sp. \\
Rubiaceae & Begoniaceae \\
Urochloa arrecta & Commelina diffusa \\
& Commelina sp. \\
& Cyperus sp. \\
& Egeria najas \\
& Eichornia crassipes \\
& Eleocharis minima \\
& Heteranthera sp. \\
& Hymenachne sp. \\
& Ludwigia sp. \\
& Myriophyllum aquaticum \\
& Paspalum sp. \\
& Penissetum purpureum \\
& Poaceae sp.1 \\
& Poaceae sp.2 \\
& Potamogeton sp. \\
& Rhynchospora sp. \\
& Rubiaceae \\
& Urochloa subquadripara \\
\hline & \\
&
\end{tabular}

could not be estimated in seven out of the eight dominated sites for there were no native species, and in the one dominated site where two native species were found co-occurring with the invasive the index was 0.8 . Native taxa richness varied between 3 and 5 taxa in patches without dominance of $U$. arrecta, and it was greater than in the dominated patches. The t-test showed significant differences in species richness between dominated and non-dominated stands $(\mathrm{t}=-7.87$; DF $=7 ; p<0.001$; Figure $3 \mathrm{~A})$.

Total plant biomass varied between $6 \mathrm{gDW} /$ $\mathrm{m}^{2}$ and $1959 \mathrm{gDW} / \mathrm{m}^{2}$, with mean values of $449 \pm 218 \mathrm{gDW} / \mathrm{m}^{2}$ in the dominated and $113 \pm 85$ $\mathrm{gDW} / \mathrm{m}^{2}$ in the non-dominated sites. The highest values were found in the mono-specific stands of $U$. arrecta, expressing its high productivity in comparison with the other species. Total biomass difference between dominated and non-dominated locals was highly significant $(\mathrm{t}=3.98 ; \mathrm{DF}=7$; $p=0.005)$. Considering only native species biomass, the difference between dominated and non-dominated locals was also significant $(\mathrm{t}=3.36$; $\mathrm{DF}=7 ; p=0.01$; Figure 3B).

\section{Discussion}

Our cumulative taxa curves together with the t-test of taxa richness, Shannon diversity and plant biomass, evidenced that macrophyte assemblages in patches dominated differ significantly from those non-dominated by $U$. arrecta. In addition, the cumulative taxa curve found in non-dominated patches did not approximate an asymptote. Rather it showed more species could be found if sampling efforts were increased in these sites, differently from

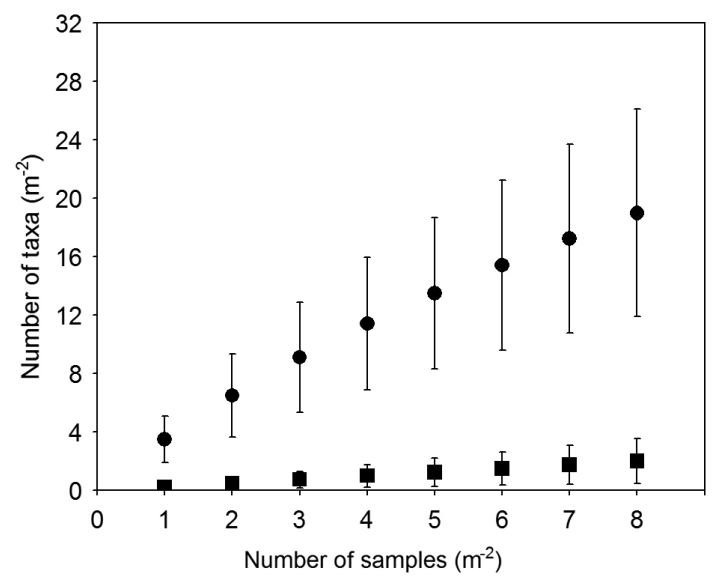

Figure 2. Taxa cumulative curve of aquatic macrophytes in streams in Northwest Paraná. Squares represent locals dominated by $U$. arrecta and circles represent nondominated locals. Bars represent standard deviation. 

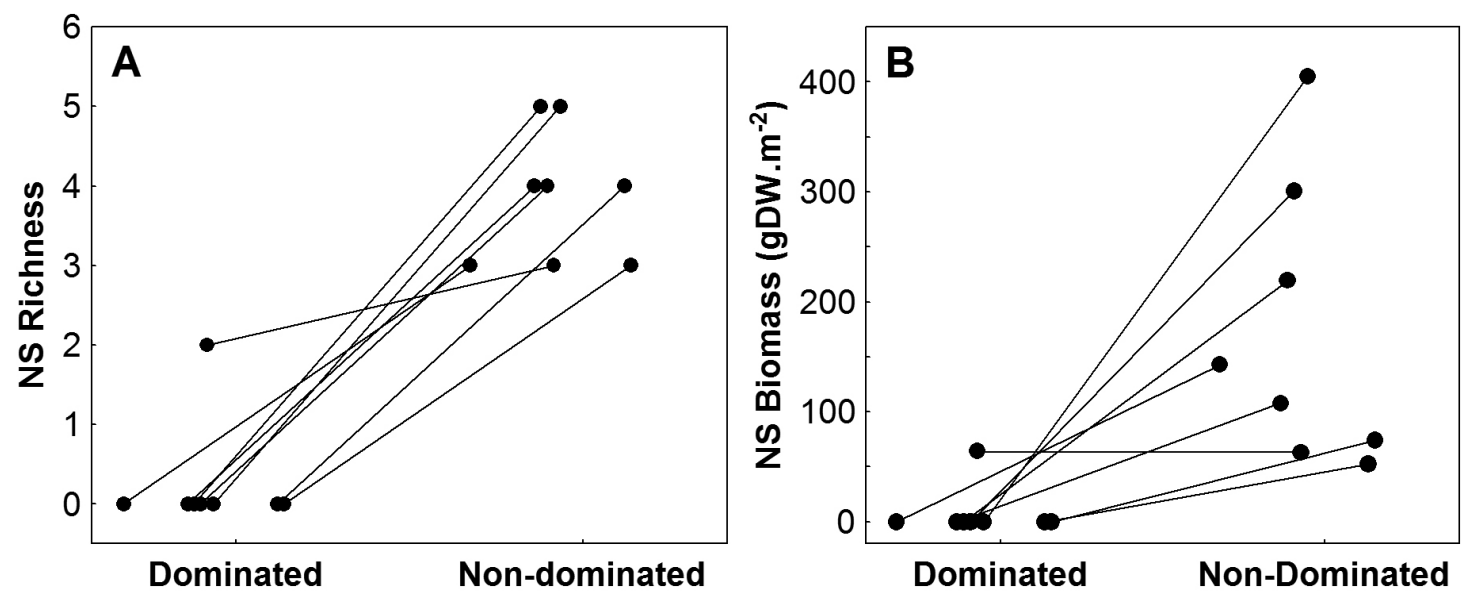

Figure 3. Native species taxa richness (A) and native species biomass (B) in patches dominated and not dominated by $U$. arrecta.

the dominated ones, where an asymptote indicates that the full richness has been recorded.

It is difficult to conclude about causes when an observational, "space-for-time" approach, like ours, is used in Invasion Biology. In fact, the use of this approach does not allow concluding whether an invasive species success causes negative impacts on native assemblages or is the result of lower biotic resistance of native assemblages in less rich sites (Thomaz et al., 2012). Thus, considered together, our results suggest two non-exclusive mechanisms: (i) the invasive species caused an intense negative influence upon native macrophytes assemblages in streams and/or (ii) the invasive species reached lower success in patches where native plants were well developed ("Biotic Resistance" hypothesis).

Considering the alternative (i), our findings are in line with several other investigations showing impacts of invasive species on other organisms and ecosystems (Madsen et al., 1991; Bunn et al., 1998; Pelicice and Agostinho, 2009; Michelan et al., 2010). When it becomes dominant, invasive Poaceae (like $U$. arrecta) makes stands practically mono-specific, lowering biotic heterogeneity and changing habitat complexity (Negrisoli et al., 2006). In a recent investigation in streams on the coast of the State of São Paulo, Amorim (2012) showed that native macrophyte richness in patches dominated by $U$. subquadripara were much lower than in patches dominated by a native species (Eichhornia azurea Kunth), indicating impacts of the invasive species.

However, we can not discard that the absence or lower biomass of $U$. arrecta in sites with higher macrophyte diversity could be the result of biotic resistance (alternative ii), since this mechanism has been shown experimentally for this species of Poaceae (Michelan et al., 2013). However, our results suggest that once this species succeeds in less rich sites, it accumulates great amounts of biomass, which can prevent native macrophytes to establish. Thus, independent of the mechanism, we suspect that $U$. arrecta will have negative impacts on native assemblages by competitively eliminating native species (alternative i) or colonizing less rich patches, avoiding native macrophytes to develop (alternative ii). In both cases, potential impacts could be caused by the significantly high biomass values observed in stands dominated by $U$. arrecta in comparison to those measured for non-dominated stands. According to Schultz and Dibble (2011), high productivity is one of the main mechanisms that lead to impacts by macrophyte invasions in native communities. U. arrecta's populations dominate the shores of streams and prevent the establishment of other species, mainly because of the quick formation of very dense beds that reduce space and light availability. The reduction in light availability may influence all biological types of macrophytes, but the submerged ones (like Myriophyllum aquaticum and Egeria najas, recorded in our survey) are most affected and practically eliminated where $U$. arrecta is dominant (Thomaz and Michelan, 2011).

In addition to high productivity, the relatively low decomposition rates of $U$. arrecta may also explain the huge accumulations of dead organic matter of this species. The half-life of a congener, $U$. subquadripara (Trin.) Hitch., registered in oligotrophic tropical environments, is around 6.3 years (Rocha, 2012), while the half-life of a largely distributed native macrophyte, like Eichhornia azurea (Sw.) Kunth, was estimated in only 0.4 years (Pagioro and Thomaz, 1998). Considering 
decomposition rates, and the fact that $\mathrm{C} 4$ plants usually suffer lower herbivory pressure (Bunn et al., 1997 ) it is expected that great amounts of biomass accumulate in littoral zones of streams (Bunn et al., 1998), and we indeed observed this during our samplings.

Our field observations also allow us to infer about the importance of dense and well conserved riparian vegetation in preventing invasion by $U$. arrecta. Among the 20 streams we visited, we did not find dominance or sometimes not even occurrence of $U$. arrecta in those that had well preserved riparian vegetation (data not shown). Despite the lack of information on propagule pressure in these streams, there are strong evidences that shading by riparian forest restrains colonization by and establishment of invasive plants (Bunn et al., 1998). Still, riparian vegetation provides seed and propagules that allow the constant occupation of occasionally empty niches by native species, imposing biotic resistance to invasions (Von Holle et al., 2003).

In conclusion, our hypothesis were not rejected, for the stands dominated by $U$. arrecta showed lower taxa richness, diversity and native plant biomass in comparison to stands where the invader was not dominant or absent. Indeed, seven out of eight sites dominated by this Poaceae were not colonized by native macrophtyes. Our results can be the outcome of impacts caused by $U$. arrecta in lotic ecosystems, mainly through its high biomass, although biotic resistance by native communities could also be an explanation. However, because of its high productivity, once this macrophyte is established it probably interferes negatively in aquatic macrophytes assemblages, and probably it does also in associated organisms, such as invertebrates and fish. Freshwater ecosystems are fundamental to the planet's biodiversity and should be preserved at any cost. To do so, the colonization of these environments by exotic species should be avoided by preventive actions that offer to ecosystems resistance against invasions. These actions could include informing nearby population about this species and its consequences to the environment, mechanical removal in early invasion stages and native aquatic and riparian vegetation restoration.

\section{Acknowledgements}

M. C. Teixeira acknowledges the National Council for Scientific and Technological Development (CNPq) for providing a scholarship. S. M. Thomaz is especially thankful to CNPq for continuous funding through a Research Productivity Grant. The authors also thank Valmir Alves Teixeira, Thaísa Sala Michelan, Roger Paulo Mormul, Eduardo Ribeiro da Cunha and Mary Pat Budd.

\section{References}

AGOSTINHO, AA., THOMAZ, SM., GOMES, LC. and BALTAR, SLSM. 2007. Influence of the macrophyte Eichhornia azurea on fish assemblage of the Upper Paraná River floodplain (Brazil). Aquatic Ecology, vol. 41, p. 611-619. http://dx.doi. org/10.1007/s10452-007-9122-2

AMORIM, SR. 2012. Efeito da biomassa da espécie exótica (Brachiaria subquadripara (trin.) hitchc.) e nativa (Eichhornia azurea (sm.) Kunth) sobre a estrutura da comunidade de macrófitas aquáticas. Rio Claro: Universidade Estadual Paulista. [Dissertação de Mestrado em Ciências Biológicas].

BUNN, SE., DAVIES, PM. and KELLAWAY, DM. 1997. Contributions of sugar cane and invasive pasture grass to the aquatic food web of a tropical lowland stream. Marine and Freshwater Research, vol. 48, p. 173-179. http://dx.doi.org/10.1071/ MF96055

BUNN, SE., DAVIES, PM., KELLAWAY, DM. and PROSSER, IP. 1998. Influence of invasive macrophytes on channel morphology and hydrology in an open tropical lowland stream, and potential control by riparian shading. Freshwater Biology, vol. 39, p. 171-178. http://dx.doi.org/10.1046/ j.1365-2427.1998.00264.x

CARACO, NF., COLE, JJ., FINDLAY, S. and WIGAND, C. 2006. Vascular plants as engineers of oxygen in aquatic systems. BioScience, vol. 56, p. 219-225.

CASATTI, L., MENDES, HF. and FERREIRA, KM. 2003. Aquatic macrophytes as feeding site for small fishes in the Rosana reservoir, Paranapanema River, southeastern Brazil. Brazilian Journal of Biology, vol. 63, p. 213-222. http://dx.doi.org/10.1590/ S1519-69842003000200006

COLWELL, RK. 2005. EstimateS: statistical estimation of species richness and shared species from samples. Version 7.5.

CORBIN, JD. and D'ANTONIO, CM. 2012. Gone but not forgotten? Invasive plants' legacies on community and ecosystem properties. Invasive Plant Science and Management, vol. 5, p. 117-124. http://dx.doi. org/10.1614/IPSM-D-11-00005.1

DOMINGOS, VD., MARTINS, D., COSTA, NV. and MARCHI, SR. 2011. Fatores ambientais na distribuiçáo de populaçôes de Brachiaria arrecta presentes no reservatório de Barra Bonita-SP. Planta daninha, vol. 29, p. 37-49. 
DUDGEON, D., ARTHINGTON, AH., GESSNER, MO., KAWABATA, Z., KNOWLER, DJ., LÉVÊQUE, C., NAIMAN, RJ., PRIEURRICHARD, A., SOTO, D., STIASSNY, MLJ. and SULLIVAN, CA. 2006. Freshwater biodiversity: importance, threats, status and conservation challenges. Biological Reviews, vol. 81, p. 163-182. http://dx.doi.org/10.1017/S1464793105006950

ENGELHARDT, KA. and RITCHIE, ME. 2001. Effects of macrophyte species richness on wetland ecosystem functioning and services. Nature, vol. 411, p. 687-689.

HORPPILA, J. and NURMINEN, L. 2003. Effects of submerged macrophytes on sediment resuspension and internal phosphorus loading in Lake Hiidenvesi (southern Finland). Water research, vol. 37, p. 44684474.

KLEEBERG, A., KÖHLER, J., SUKHODOLOVA, T. and SUKHODOLOV, A. 2010. Effects of aquatic macrophytes on organic matter deposition, resuspension and phosphorus entrainment in a lowland river. Freshwater Biology, vol. 55, p. 326-345. http://dx.doi.org/10.1111/j.13652427.2009.02277.x

MADSEN, JD., SUTHERLAND, JW., BLOOMFIELD, JA., EICHLER, LW. and BOYLEN, CW. 1991. The decline of native vegetation under dense Eurasian watermilfoil canopies. Journal of Aquatic Plant Management, vol. 29, p. 94-99.

MARTINS, D., COSTA, NV., TERRA, MA. and MARCHI, SR. 2008. Caracterização da comunidade de plantas aquáticas de dezoito reservatórios pertencentes a cinco bacias hidrográ?cas do estado de São Paulo. Planta Daninha, vol. 26, p. 17-32.

MELO, AS. and FROELICH, GG. 2001. Macroinvertebrates in neotropical streams: richness patterns along a catchment and assemblage structure between 2 seasons. Journal of the North American Benthological Society, vol. 20, p. 1-16.

MICHELAN, TS., THOMAZ, SM., MORMUL, RP. and CARVALHO, P. 2010. Effects of an exotic invasive macrophyte (tropical signalgrass) on native plant community composition, species richness and functional diversity. Freshwater Biology, vol. 55, p. 1315-1326. http://dx.doi.org/10.1111/j.13652427.2009.02355.x

MICHELAN, TS., THOMAZ, SM. and BINI, LM. 2013. Native macrophyte density and richness affect the invasiveness of a tropical Poaceae species. Plos One, vol. 8, p. e60004. http://dx.doi.org/10.1371/ journal.pone.0060004

NEGRISOLI, E., CORRÊA, MR., VELINI, ED., BRAVIN, LF., MARCHI, SR., CAVENAGHI, AL. and ROSSI, CVS. 2006. Estudo da degradação da biomassa de três espécies de plantas aquáticas no reservatório da UHE de Americana-SP. Planta Daninha, vol. 24, p. 221-227.
PAGIORO, TA. and THOMAZ, SM. 1998. Loss of weight and concentration of carbon, nitrogen, and phosphorus during decomposition of Eichhornia azurea in the floodplain of the Upper Paraná river, Brazil. Revista Brasileira de Biologia, vol. 58, p. 603-608. http://dx.doi.org/10.1590/S003471081998000400007

PELICICE, FM. and AGOSTINHO, AA. 2009. Fish fauna destruction after the introduction of a nonnative predator (Cichla kelberi) in a Neotropical reservoir. Biological Invasions, vol. 11, p. 1789-1801. http://dx.doi.org/10.1007/s10530-008-9358-3

PELICICE, FM. and AGOSTINHO, AA. 2006. Feeding ecology of fishes associated with Egeria spp. patches in a tropical reservoir, Brazil. Ecology of Freshwater Fish, vol. 15, p. 10-19.

PENCZAK, T., AGOSTINHO, AA. and OKADA, EK. 1994. Fish diversity and community structure in 2 small tributaries of the Paraná River, Paraná State, Brazil. Hydrobiologia, vol. 294, p. 243-251. http:// dx.doi.org/10.1007/BF00021297

POTT, VJ. and POTT, A. 2000. Plantas aquáticas do Pantanal. Brasília: Embrapa. 404 p.

POTT, VJ., POTT, A., LIMA, LCP. and OLIVEIRA, AKM. 2011. Aquatic macrophyte diversity of the Pantanal wetland and upper basin. Brazilian Journal of Biology, vol. 71, p. 255-263. http://dx.doi. org/10.1590/S1519-69842011000200005

REINERT, BL., BORNSCHEIN, MR. and FIRKOWSKI, C. 2007. Distribuição, tamanho populacional, hábitat e conservação do bicudinho-dobrejo Stymphalornis acutirostris Bornschein, Reinert e Teixeira, 1995 (Thamnophilidae). Revista Brasileira de Ornitologia, vol. 15, p. 493-519.

ROCHA, RJS. 2012. Decomposição de macrófitas aquáticas em reservatórios com diferentes estados tróficos. São Carlos: Universidade Federal de São Carlos. [Dissertaçâo de Mestrado em Ecologia e Recursos Naturais].

RODRÍGUEZ, P., PIZARRO, H. and VERA, MS. 2012. Size fractionated phytoplankton production in two humic shallow lakes with contrasting coverage of free floating plants. Hydrobiologia, vol. 691, p. 285-298. http://dx.doi.org/10.1007/s10750-012-1081-5

SALARIATO, DL., ZULOAGA, FO., GIUSSANI, LM. and MORRONE, O. 2010. Molecular phylogeny of the subtribe Melinidinae (Poaceae: Panicoideae:Paniceae) and evolutionary trends in the homogenization of inflorescences. Molecular Phylogenetics and Evolution, vol. 56, p. 355-369. http://dx.doi.org/10.1016/j.ympev.2010.02.009

SANTAMARÍA, L. 2002. Why are most aquatic plants widely distributed? Dispersal, clonal growth and small-scale heterogeneity in a stressful environment. Acta Oecologica, vol. 23, p. 137-154. http://dx.doi. org/10.1016/S1146-609X(02)01146-3 
SCHULTZ, R. and DIBBLE, E. 2011. Effects of invasive macrophytes on freshwater fish and macroinvertebrate communities: the role of invasive plant traits. Hydrobiologia, vol. 684, p. 1-14. http:// dx.doi.org/10.1007/s10750-011-0978-8

Statsoft Inc. 2007. STATISTICA (data analysis software system). version 8.0.

STRAYER, DL. 2010. Alien species in fresh waters: ecological effects, interactions with other stressors, and prospects for the future. Freshwater Biology, vol. 55, p. 152-174. http://dx.doi.org/10.1111/ j.1365-2427.2009.02380.x

THOMAZ, SM. and MICHELAN, TS. 2011. Associations between a highly invasive species and native macrophytes differ across spatial scales. Biological Invasions, vol. 13, p 1881-1891. http:// dx.doi.org/10.1007/s10530-011-0008-9

THOMAZ, SM., AGOSTINHO, AA., GOMES, LC., SILVEIRA, MJ., REJMANEK, M., ASLAN, CE. and CHOW, E. 2012. Using space-for-time substitution and time sequence approaches in invasion ecology. Freshwater Biology, vol. 57, p. 2401-2410. http:// dx.doi.org/10.1111/fwb.12005

United States Department of Agriculture - USDA. 2013. ARS National Genetic Resources Program. Germplasm Resources Information Network-(GRIN). Beltsville: National Germplasm Resources Laboratory. Available from: <http://www.ars-grin.gov/cgi-bin/ npgs $>$. Access in: 18 Feb 2013.

URBAN, RA., TITUS, JE. and ZHU, WX. 2009. Shading by an invasive macrophyte has cascading effects on sediment chemistry. Biological Invasions, vol. 11, p. 265-273. http://dx.doi.org/10.1007/ s10530-008-9231-4

VON HOLLE, B., DELCOURT, HR. and SIMBERLOFF, D. 2003. The importance of biological inertia in plant community resistance to invasion. Journal of Vegetation Science, vol. 14, p. 425432. http://dx.doi.org/10.1111/j.1654-1103.2003. tb02168.x

Received: 21 June 2013 Accepted: 03 October 2013 
